\title{
TRILOBITE FAUNAL CHANGES IN THE EAST BALTIC SILURIAN
}

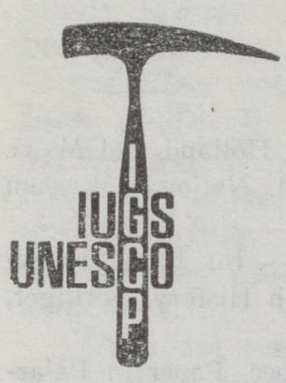

Project 216 Global Bioevents

\begin{abstract}
The major changes in the evolution of the trilobite fauna of the East Baltic Silurian are concentrated on certain stratigraphical levels and associated with depth-related facies cycles. After the terminal Ordovician event, the significant evolutionary changes in the lower Silurian occur at the Aeronian-Telychian and Llandovery-Wenlock boundaries. The Wenlock-Ludlow boundary beds lack trilobites. In the onshore area (Saaremaa Island) the earliest Late Silurian trilobites appear in the lower Ludfordian (Uduvere Beds of the Paadla Stage), characterized by a generically new low-diversity fauna. In the offshore area (Latvian Depression) the Gorstian and early Ludfordian fauna is generically similar to that of the Wenlock, and the most remarkable changes have been recorded in the late Ludfordian (lower part of the Kuressaare Stage), where new, diverse and abundant fauna appeared. Upwards this fauna disappears gradually due to the further regression. The Pridoli fauna is generically more or less homogeneous and of low diversity through the whole study area.
\end{abstract}

The terminal Ordovician event, including the global trilobite crisis, is well known and has been dealt with by several authors. Comparatively little attention has been paid to different events in the Silurian trilobite evolution and their relation to environmental changes (Chatterton et al., 1990). In the present paper the main changes in the Silurian trilobite fauna of the East Baltic, chiefly of Estonia and Latvia, are examined. In the study area two main facies regions are distinguished: (1) northern and middle Estonia, predominantly characterized by shelf platform carbonate deposits, and (2) southern Estonia and western Latvia with shelf margin and basinal argillaceous deposits (Кальо, 1977). Because of their strong dependence on lithofacies, the trilobites of these regions differ considerably not only in their taxonomic composition and abundance, but also in certain evolutionary changes. Therefore below the faunas of the two regions are for the most part examined separately.

The terminal Ordovician extinction was stepwise, beginning from the late Caradoc through the Ashgill and reaching its maximum at the Ordovician-Silurian boundary. In the East Baltic Ashgill the important Ordovician families disappeared gradually: Remopleuridae and Raphiophoridae by the end of the Vormsi age; Trinucleidae, Harpidae, and Panderidae at the Pirgu-Porkuni (= Rawtheyan-Hirnantian) boundary; Asaphidae, Pterygometopidae, and several distinctive Ordovician genera (Flexicalymene, Dalmanitina, Brongniartella, etc.) by the end of the Porkuni age ( $=$ the systemic boundary) (Неcrop et al., 1991). However, the extinction

\footnotetext{
* Eesti Teaduste Akadeemia Geoloogia Instituut (Institute of Geology, Estonian Acad-
} emy of Sciences), Estonia pst. 7, EE0105 Tallinn. Estonia. 
rate was different in the two facies regions. In northern Estonia, where shallow-water provincial associations were predominant (Мянниль, 1966; Jaanusson, 1979), the diversity decrease at the Pirgu-Porkuni boundary was relatively insignificant. About $2 / 3$ of the genera and a number of species of the Pirgu Stage extend into the Porkuni Stage, and the latter has yielded relatively numerous (13) genera (Мянниль, 1962). Contrary to this, in the lower and middle Ashgill of the Latvian Depression the wide-spread trinucleid associations (so-called Tretaspis fauna) disappear at the same boundary. Trinucleids are very uncommon in the post-Rawtheyan strata also elsewhere (Thomas et al., 1984; Lespérance, 1988). The late Ashgill Kuldiga Formation of the Porkuni Stage is characterized by the lowdiversity, almost cosmopolitan Dalmanitina fauna, represented by two species - Mucronaspis mucronata (Brongniart) and Brongniartella platynota (Dalman) (Гайлите, 1975, 1982; Мянниль, 1966; Мянниль et al., 1968). This is in good accordance with the analysis of the fate of Rawtheyan trilobite genera across the ecological spectrum, which shows that extinctions were disproportionately concentrated in deeper water environments (Owen et al., 1991).

The major evolutionary crisis was followed by a profound faunal innovation in the early Silurian. Only five genera appear to cross the systemic boundary. The basal Silurian is recognized by the appearance of the family Phacopidae and several new genera, including the key Llandovery genera Acernaspis and Nucleurus, and the typical Silurian genus Calymene (Fig. 1). However, as a rule the lowermost Llandovery contains only an impoverished trilobite fauna or no trilobites at all, although the first specimens have been recorded already from the acuminatus Zone (Чугаева, 1983; Thomas et al., 1984; Lespérance, 1985).

The first considerable diversity increase on both generic and species level is noted in shoaly (including biohermal) sediments of the Hilliste Member of the Tamsalu Formation (Figs. 1 and 2). From the overlying deposits of the Raikküla Formation, also only sparse shallow-water trilobites have been found. The maximum rise in diversity is recorded in the

\begin{tabular}{|c|c|c|c|}
\hline Series & Regional stages & Number of genera & \\
\hline \multirow{2}{*}{ Pridoli } & Ohesaare & 4 & \\
\hline & Kaugatuma & 4 & \\
\hline \multirow{2}{*}{ Ludlow } & Kuressaare & 9 & \\
\hline & Paadla & 6 & \\
\hline \multirow{3}{*}{ Wenlock } & Rootsiküla & & \\
\hline & Jaagarahu & 20 & \\
\hline & Jaani & 10 & \\
\hline \multirow{3}{*}{$\begin{array}{l}\text { Llan- } \\
\text { dovery }\end{array}$} & Adavere & 5 & 13 \\
\hline & Raikküla & 11 & \\
\hline & Juuru & 10 & 14 \\
\hline Ashgill & Porkuni & & 2315 \\
\hline
\end{tabular}

Fig. 1. Diversity chart of uppermost Ordovician and Silurian trilobite genera in East Baltic. Densely striped sections indicate the number of appearing genera. 
uppermost Aeronian Rumba Formation. This trilobite radiation is characterized by the appearance of a number of new species and some shortranging genera (Radiurus, Distyrax, etc.) and it probably corresponds to $C_{2}-C_{3}$ Bioevent by Boucot (1990).

In southern Estonia and northern Latvia the Juuru Stage and the main part of the Raikküla Stage are characterized by rare trilobites, predominantly by different species of Acernaspis and Nucleurus. In the study area the earliest Silurian trilobite, Acernaspis, has been found about $10 \mathrm{~m}$ above the Ordovician-Silurian boundary (Ohesaare core) or $14 \mathrm{~m}$ higher than the last occurrence of the Dalmanitina fauna (Ikla core). The generic similarity and low frequency of the trilobite fauna character-



Fig. 2. Diversity curves of Silurian trilobite species, $A-$ in middle Estonia, $B$ - in southern Estonia and western Latvia. Dashed line indicates the diversity changes on the level of regional stages, continuous line - smaller stratigraphical units. Sea-level curve after Johnson, Kaljo and Rong (1991). 
ize the basal Silurian beds also elsewhere (Bolton, 1981; Cocks et al., 1983; Чугаева, 1983). A remarkable increase in the diversity and frequency occurs in the upper Staicele Member of the Raikküla Stage of northern Latvia (convolutus Zone). Dark grey calcareous argillites of this member have yielded a rich and diverse deep-water association, dominated by species of Calymene, Nucleurus, and Acernaspis (Мянниль, 1986). These beds may be correlated with the cometa Biozone in Scandinavia and correspond to the convolutus-sedgwickii boundary transgression (Johnson, Kaljo and Rong, 1991).

In general, the East Baltic trilobite fauna of Rhuddanian and Aeronian ages is relatively homogencous by dominating genera, showing difference mainly in the species composition and locally in the occurrence of some stenotopic genera of a restricted distribution. However, the following Telychian transgression, which brought the argillaceous deep shelf sediments also to the middle Estonia (Johnson, Baarly et al., 1991; Kыртс et al., 1991), caused a notable evolutionary change, observed in both studied regions. Apart from the disappearance and probable extinction of some short-ranging genera the Rumba-Velise boundary is associated also with the extinction of the important Llandovery genera Stenopareia and Nucleurus, which had extended upwards from the middle Ordovician and lowermost Silurian, respectively, Nucleurus is replaced by Encrinurus (E.), which in the Velise time is represented already by two species and is very common in the Wenlock and lower Ludlow deep-shelf sections. At this boundary also an almost complete turnover of species takes place (except the facially tolerant Calymene frontosa Lindström). As a rule, the deepshelf (basinal) sediments contain a trilobite fauna of lower diversity but higher frequency than that of the open shelf sediments. The argillaceous deposits of the Velise Formation have yielded a moderately diverse and frequent association, common to both facies regions (Fig. 2).

Though the Llandovery-Wenlock boundary beds contain rare trilobites (probably due to the maximum transgression), these show the next remarkable evolutionary event. The Llandovery type genus Acernaspis disappeared finally and Proetus, which is very characteristic of the Wenlock and Ludlow, appeared. In the Latvian Depression no trilobites have been found from the basinal sediments of the lowermost Wenlock, but beginning from the uppermost riccartonensis Zone there is a gradual incoming of a new fauna, dominated by abundant specimens of Dalmanites and species of the Calymene orthomarginata lineage (Мянниль, 1982). An almost complete change occurs also on the species level: only Calymene frontosa extends to the basal Wenlock in the Ohesaare core as well as in the Gotland section (Bruton et al,, 1979). The Jaani-Jaagarahu boundary is not defined by trilobites. It is the only boundary of stages crossed by the dominant species. Still, the Jämaja Formation shows the appearance of the genus Cyphoproetus and several new species, which considerably increases the diversity (Fig. 2). Yet their horizontal and vertical distribution is restricted and therefore no remarkable events have been recorded. Higher, due to prolonged regression, the diversity decreases considerably and practically no trilobites have been found from the uppermost Jaagarahu Stage, the Rootsiküla Stage, and the basal part of the Paadla Stage (Fig. 2). So, the Wenlock-Ludlow boundary cannot be identified by trilobites.

The Ludlow trilobite fauna differs considerably in the two facies regions. In the outcrop area no trilobites are known from the lower Sauvere and Himmiste members. The fauna, first appearing in the Uduvere Beds, differs on the generic level completely from that of the Wenlock, being represented by the genera Balizoma and Pulcherproetus, and the first member of the Calymene tentaculata lineage. Different species of 
Pulcherproetus and Calymene dominated in the outcrop area until the end of the Silurian.

In the Latvian Depression Ludlow trilobites are considerably more diverse and frequent and their generic composition is different. No trilobites have been recorded from the nilssoni Zone, but beginning with the scanicus Zone, the well-known Wenlock genera Encrinurus, Dalmanites, and Proetus (in different species associations) continue throughout the Dubysa and Engure formations, in certain intervals being accompanied by short-ranging genera (Linguocalymene, Tetinia, etc.). This fauna has specific affinities with the Hemse Beds of Gotland and the leintwardinensis Zone of the Welsh Borderland. An abrupt change is observed on the supposed Paadla-Kuressaare boundary (Pavilosta borehole, $740 \mathrm{~m}$ ), marked by the disappearance of Encrinurus and Dalmanites and a complete turnover of species. There appears a diverse and abundant association, containing the species of Ananaspis, Harpidella, Ryckholtia, etc. It has at least generic affinities with the fauna of the Ananaspis fecunda Zone of the Kopanina Formation of Bohemia. In the upper half of the stage the association becomes impoverished and disappears gradually.

The Ludlow-Pridoli boundary is rather poorly marked by trilobites and a further decrease in the generic diversity characterizes the Pridoli trilobite faunas almost everywhere (Fig. 1). The continuing regression caused the formation of the open-shelf environment and the appearance of more or less homogeneous shallow-water association almost on the whole study area. It is dominated by the species of Pulcherproetus and Calymene, accompanied by rare Eophacops and Acaste. The considerable increase in the species diversity and frequency, observed in the Aigu Beds of the Kaugatuma Stage, is associated mainly with the radiation of Calymene.

Conclusions. The evolution of the trilobite fauna in the East Baltic Silurian may be divided into the cycles which in general correspond to the depth-related lithofacies cyclothemas identified by Einasto in the Silurian of Estonia (Kыртc et al., 1991). The extent of the early Silurian cycles is similar in both facies regions discussed: (1) Rhuddanian-Aeronian and (2) Telychian; but rather different in higher strata. In the outcrop area there follow (3) Sheinwoodian-lower Homerian and (4) lower Ludfordian to uppermost Silurian; in the Latvian Depression and southern Estonia the following cycles are: (3) Sheinwoodian-lower Ludfordian, (4) upper Ludfordian, and (5) Pridoli. Besides, the Telychian cycle is rather transitional between the Llandovery and Wenlock faunas.

These cycles are separated by extinction/emigration periods. The most impressive and widespread extinction/innovation periods (events) are distinguished at the Aeronian-Telychian and Llandovery-Wenlock boundaries. The extinction/emigration events occur at the Wenlock-Ludlow boundary beds in the whole study area, and at the lower to upper Ludfordian and Ludlow-Pridoli boundaries in the Latvian Depression. The trilobite faunal turnovers correspond rather well to environmental changes and the extinction/emigration events are caused by extreme facies conditions. A new trilobite fauna appears usually either at the onset of transgression (observed in the convolutus Zone, Velise Formation, Uduvere Beds) or more or less gradually during prolonged regressions (Riga and Jämaja formations and the boundary beds of the Dubysa and Engure formations).

Acknowledgements. I am grateful to Prof. D. Kaljo for his encouragement and critical reading of the manuscript, to Mrs. A. Noor for linguistic help, and to Mrs. K. Ronk for drawing the figures. 
Bolton, T. E. 1981. Ordovician and Silurian Biostratigraphy, Anticosti Island, Quebec. Subcom. Sil. Strat. Ord.-Sil. Boundary Working Group. Field Meeting Anticosti-Gaspe, Quebec, 2, Stratigraphy and Paleontology, 41-60.

Boucot, A. J. 1990. Silurian and pre-Upper Devonian bio-events. - In: E. G. Kauffman, O. H. Walliser (eds.). Extinction Events in Earth History. Lecture Notes in Earth Sciences, 30, 126-132.

Bruton, D. L., Jaanusson, V., Owens, R. M., Siveter, D. J., and Tripp, R. 1979. Trilobites. - In: V. Jaanusson, S. Laufeld, and R. Skoglund (eds.). Lower Wenlock faunal and floral dynamics - Vattenfallet Section, Gotland. Sver. Geol. Undersökn., Serie C, 762, 116-120.

Chatterton, B. D. E., Edgecombe, G. D., and Tuffnell, P. A. 1990. Extinction and migration in Silurian trilobites and conodonts of northwestern Canada. - J. Geol. Soc. London, 147, 703-715.

Cocks, L. R. M., Lane, P. D., Rickards, R. B., Temple, J. T., and Woodcock, N. H. 1983. The Llandovery area as the type for the first series of the Silurian System. Report to the Subcommission on Silurian Stratigraphy.

Jaanusson, V. 1979. Ordovician. - In: R. A. Robinson, C. Teichert (eds.). Treatise on Invertebrate Paleontology. A. Introduction, Fossilification (Taphonomy), Biogeography and Biostratigraphy. Geol. Soc. America and Univ. of Kansas Press, Lawrence, A136-A166.

Johnson, M., Baarly, G., Nestor, H., Rubel, M., Worsley, D. 1991. Eustatic sea-level patterns from the Lower Silurian (Llandovery Series) of southern Norway and Estonia. - Geol. Soc. Amer. Bull., 103, 315-335.

Johnson, M. E., Kaljo, D., Rong, J.-Y. 1991. Silurian eustasy. - In: M. G. Bassett, P. D. Lane, and D. Edwards (eds.). The Murchison Symposium. The Paleontological Association, Special Papers in Palaeontology, 44, 145-163.

Lespérance, P. J. 1985. Faunal distribution across the Ordovician-Silurian boundary, Anticosti Island and Percé, Quebec, Canada. - Canad. J. Earth Sci., 22, 838849.

Lespérance, P. J. 1988. Trilobites. - In: L. R. M. Cocks and R. B. Rickards (eds.). A global analysis of the Ordovician-Silurian boundary. - Bull. Brit. Museum (Natur. History). Geol., 43, 359-37.6.

Owen, A. W., Harper, D. A. T., Rong, J. 1991. Hirnantian trilobites in the space and time. - In: C. R. Barnes, S. H. Williams (eds.). Advances in Ordovician Geology. - Geol. Surv. Canada, Paper 90-9, 179-190.

Thomas, A. T., Owens, R. M., and Rushton, A.W. A. 1984. Trilobites in British stratigraphy. - Geol. Soc. London, Spec. Report, 16.

Гайлите Л. К. 1975. Трилобиты верхнего ордовика Латвии. - In: А. А. Григялис (ed.). Фауна и стратиграфия палеозоя и мезозоя Прибалтики и Белоруссии. Вильнюс, Минтис, 5-19.

Гайлите Л. К. 1982. Трилобиты. - In: Р. Ж. Ульст, Л. К. Гайлите, В. И. Яковлева (eds.). Ордовик Латвии. Рига, Зинатне, 101-114.

Кальо Д. Л. 1977. Структурно-фациальное районирование силура Прибалтики. In: Д. Л. Кальо (еd.). Фация и фауна силура Прибалтики. Таллинн, АН ЭССР, 6-13.

Кыртс А. Л., Мянниль Р. М., Пылма Л. Я., Эйнасто Р. Э. 1991. Этапы и обстановки накопления кукерситовой (водорослевой) органики в ордовике и силуре Эстонии. - In: Важнейшие биотические события в истории Земли. Tp. XXXII сессии ВПО, 87-95.

Млнниль Р. М. 1962. Фаунистическая характеристика поркуниского горизонта. Тр. Ин-та геол. АН ЭССР, 10, 115-129.

Мянниль Р. М. 1966. История развития Балтийского бассейна в ордовике. Таллинн, Валгус, 1-199.

Мянниль Р. П. 1982. Сообщества трилобитов (венлок Прибалтики). - In: Д. Кальо, Э. Клааманн (eds.). Сообщества и биозоны в силуре Прибалтики. Таллинн, Валгус, 51-62. 
Мянниль Р. П. 1986. Распределение трилобитов в разнофациальных отложкених силура Прнбалтики. - In: Д. Л. Қальо, Э. Р. Қлааманн (eds.). Теория и опыт экостратиграфик. Таллинн, Валгус, 99-109.

Мянниль Р. М., Пылма Л. Я., Хинтс Л. М. 1968. Стратиграфия вируских и харьюских отложений (ордовик) Средней Прибалтики. - In: A. А. Григялис (ed.). Стратиграфия нижнего палеозоя Прибалтики и корреляция с другими регнонами. Вильнюс, Минтис, $81-110$.

$\checkmark$ Нестор Х. Э., Клааманн Э. Р., Мейдла Т. Р., Мяниик П. П., Мяниило Р. П., Нестор В. В., Нылеак Я. Р., Рубель М. П., Сарв Л. Я., Хинтс Л. М. 1991. Динамика фауны в Балтийском бассейне на границе ордовика и силура. In: Д. Л. Кальо, Т. Л. Модзалевская, Т. Н. Богданова (eds.). Важнейшие биотические события в истории Земли. Тр. ХХXII сессии ВПО, 79-86.

Чулаева М. Н. 1983. Трилобиты. - In: Б. С. Соколов, Т. Н. Корень, И. Ф. Ннкитин (eds.). Граница ордовика и силура на северо-востоке СССР. Ленинград, Наука, $73-97$.

Presented by D. Kaljo

Received May 26, 1992

Reet MANNIL

\section{TRILOBIIDIFAUNA MUUTUSED BALTIKUMI SILURIS}

On käsitletud olulisemaid muutusi Baltikumi trilobiidifauna arengus ordoviitsiumi ja siluri piiril ning siluri vältel seoses fatsiaalsete muutustega.

tho sill valtel seoses falsiaalsete muthistega.

Bait?

Рээт МЯННИЛЬ

\section{ИЗМЕНЕНИЯ ТРИЛОБИТОВОЙ ФАУНЫ В СИЛУРЕ ПРИБАЛТИКИ}

Рассматриваются наиболее существенные изменения в таксономическом составе и видовом разнообразни трилобитовой фауны на границе ордовика и силура иі в силуре Прибалтики, произошедшие в результате смены фациальных условий.

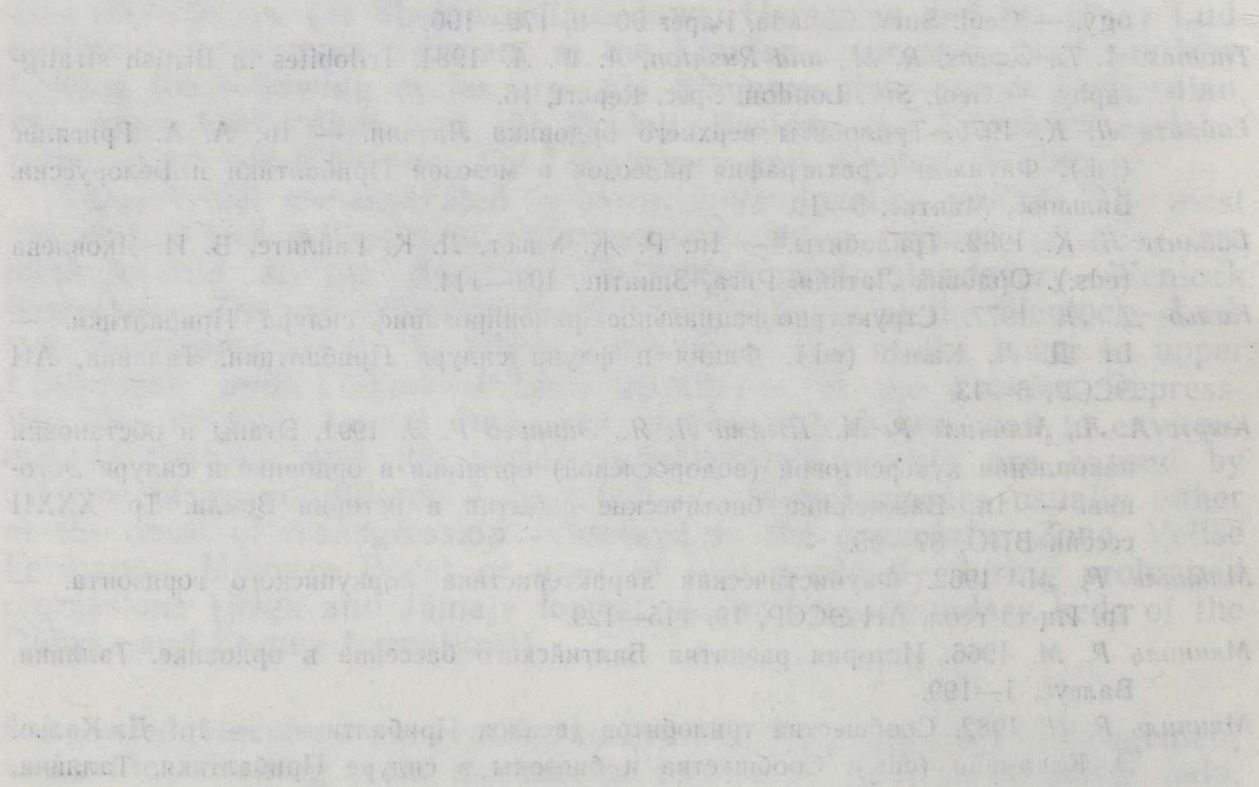

